\title{
Tax Havens: Toward An Optimal Selection Approach Based On Multicriteria Analysis
}

Tov Assogbavi, Laurentian University, Canada

Sébastien Azondékon, Université du Québec, Canada

\begin{abstract}
The purpose of this paper is to demystify the concept of tax havens. After defining tax havens in a tax-planning framework, the paper introduces a tax haven selection methodology based on a variant of Gibson and Black multicriteria analysis to identify the most suitable tax haven for a given entity. The study shows the importance of subjective variables and how to incorporate them into a tax haven selection process. While tax advantages remain the key factor when searching for a tax haven solution, our study shows that non-quantifiable factors are also crucial in determining the most suitable tax haven for a given entity.
\end{abstract}

\section{INTRODUCTION}

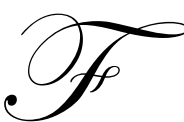

or many years, the governments of developed countries have blamed tax shelters and tax evasion schemes as some of the major causes of their financial distress in terms of lost tax dollars and have been trying to combat and eradicate any future tax haven development ${ }^{1}$. However, if tax fraud in the form of tax evasion is a criminal act both immoral and condemnable, the creation of tax shelters to reduce one's taxation burden is acceptable and widely recommended. From this point of view, it is the responsibility of each individual or corporation to make good use of existing taxation legislations and to reduce the total amount of tax paid. Tax havens are a recent economic phenomenon and their progression is expected to continue ${ }^{2}$. In fact, there are an increasing number of countries that are adapting their legislation to create their own version of tax havens. In essence, incorporating low tax legislation into domestic policy can signify major sources of capital inflow, a way of generating additional income that cannot be overlooked. It also guarantees long-term employment for local residents. For some economists, the presence of tax shelters forces the economy towards liberalization by creating tax competition among nations. This allows for the reduction of tax burdens by shifting capital and labor from high-tax jurisdictions to low-tax jurisdictions. For Milton Friedman ${ }^{3}$, this creates competition among national governments in the public services they provide and in the taxes they impose. This is similar to price competition among individuals or corporations in goods and services. Therefore, the migration of funds from high-tax bracket countries towards low tax-bracket countries increases global economic benefits of certain regions, since a lower tax rate increases the individual's incentives to work, save and invest. However, because of their controversial existence, only very few publicly accessible documents instructing proper setup exist. While there are many professionals specializing in tax havens, the choice of a tax haven remains a quasi-objective one. As a tax haven's goal is not only a financial one, numerous individuals and corporations may want to go for a tax haven for many other purposes that will substantially impact the tax haven of their choice. The methodology of choosing the most appropriate tax haven cannot then be only a quantitative one. It has to also encompass subjective criteria to account for individual preferences that suit immediate and long-term needs. The purpose of this paper is to demystify the concept of tax havens and to formulate

${ }^{1}$ Gregory Rawlings "Taxes and Transnational Treaties: Responsive Regulation and the Reassertion of Offshore Sovereignty" Law \& Policy. Oxford: Jan 2007. Vol. 29, Iss. 1; pg. 51

${ }^{2}$ For William Britain-Catlin, Procter \& Gamble, DuPont, IBM would not have become the massive, integrated organizations they are today without the direct involvement of tax havens. Tax havens allowed these huge companies to retain their profits and so allowed them to expand exponentially across Europe and elsewhere. So without, tax havens, U.S. corporations would have found it too expensive and time-consuming to internationalize.

${ }^{3}$ Milton Friedman and Rose friedman: Free to Choose: A Personal Statement. Editions: Books: Milton Friedman January 1980 
an analytical selection tool based on a variant of Gibson and Brown's ${ }^{4}$ location methodology that encompasses both quantitative and qualitative factors in order to identify the most suitable tax haven for a given entity. The remaining of the paper is organized as follows: in section II, tax havens are defined, in section III, factors of tax haven selection are covered. Finally, section IV presents a multicriteria selection approach and Section V concludes the paper.

\section{TAX HAVENS AND THEIR EVOLUTION}

Tax havens are a recent economic phenomenon and their progression is expected to continue. These tax creations are in essence, an oasis for some, if not sanctuaries and refugee camps for others. They are the necessary steps to security, and defense mechanisms against an oppressive tax regime that has evolved within a new-aged globalized society. Globalization, the suppression of trade barriers, lesser controls over exchange rates, economic and political instability, the mobility of labor, and the high tax policies of the industrialized nations are all contributing growth factors to tax haven markets. Their growth rates are substantial: the tax haven market captures more than 100000 surplus subsidiaries each year. Two decades have passed since a handful of countries have discovered the benefits of offering tax haven sanctuary. Since then, many countries have adapted their own legislation or have even created their own version of tax haven societies, hoping to attract international commerce to their area. Integrating low tax legislation into domestic policy can significantly increase capital inflow ${ }^{5}$ and create long-term job opportunities. Currently, there are more than forty known tax havens throughout the world and the expansion continues. In the Cayman Islands alone, there more than 65,000 companies registered. And according to the Guardian, 2004, roughly 150,000 offshore companies are being formed a year.

Even though the tax haven phenomenon is on the rise, the term "tax haven" is not always easy to interpret, mainly because it has taken on so many different connotations. By simple definition, a tax haven is any country whose laws, regulations, traditions and in some cases, treaty arrangements, make it possible to reduce one's overall tax burden. On its part, The Economist has tentatively adopted the description by Colin Powell (former Economic Adviser to Jersey): "What ... identifies an area as a tax haven is the existence of a composite tax structure established deliberately to take advantage of, and exploit, a worldwide demand for opportunities to engage in tax avoidance." However, "The Economist points out that this definition would still exclude a number of jurisdictions traditionally thought of as tax havens" . It is also important to mention that many schemes have been devised to take advantage of the loopholes in most tax systems. To elaborate on this, Caroline Doggart recognized the advantage of fixing different price margins for goods when transferring them from the parent company to the subsidiary abroad. By doing this, they were also able to boost fraudulent, non-existent enterprise set-ups. As a result, they made a profit from the gap between markups. Such schemes may reinforce the legalities of the system, making it difficult for others to profit from such flaws. As an added function, many of these subsidiaries are utilized as shelters for rollover investment funds or for repatriates. A few other advantages include protection from inflation, reductions in operating expenses and local government concessions, subsidies and support. So, a tax haven may have different definitions. Within the context of this study, a tax haven will be defined as a country or territory where a wealthy individual, either physically (having a local presence) or indirectly (meaning that he oversees operations from his resident country), may establish a legal tax shelter with advantages that extend further than those offered in his originating country. This individual may benefit by reducing his tax burden to benefit from a less tax-abrasive society by either self-managing an account or by forming a trust. However, there is a minimum infrastructure a country needs to have in place in order to become attractive to tax haven seekers. So some major factors will be defined and taken into

\footnotetext{
${ }^{4}$ Brown, P.A. and D.F. Gibson, 'A quantified Model for Site Selection : Application to a Multiplant Location Problem ‘ , AIIE Transactions, March 1982

5 According to the "Tax Justice Network", an anti-tax haven pressure group, suggests that global tax revenue lost to tax havens exceeds US $\$ 255$ billion per annum, although those figures are not widely accepted. Estimates by the OECD suggest that by 2007 capital held offshore amounts to somewhere between US\$5 trillion and US\$7 trillion, making up approximately 6-8\% of total global investments under management. Of this, approximately US $\$ 1.4$ trillion is estimate to be held in the Cayman Islands alone.

${ }^{6}$ Doggart, Caroline. . 2002. "Tax Havens and their uses" (originally published 1970), Economist Intelligence Unit, ISBN 0862181631
} 
account in our analysis. These major factors will be presented in the next section before moving into the multicriteria tax haven selection methodology. It is important to know that proper tax planning is a lengthy process that must be performed with diligence. And a tax haven plan is in line with the concept of a work-in-progress, consisting of a discrete and prudent operational plan. According to Caroline Doggart, depending on the desired criteria, each tax haven holds specific benefits to corporations or wealthy individuals. Fiscal authorities have indicated the complexity of policing capital movements, making most anti-tax haven regulations ineffective. This effort of the G-8 industrialized countries in preventing their citizens from taking advantage of existing tax havens is essentially a limitation towards liberalism of the capital market, reducing the overall effectiveness of the economy. The only foreseeable effective anti-tax haven policy would have been a convergence of forces among all major developed nations to denounce the tax legislation imposed by the smaller ones benefiting from making use of tax havens. However this is unlikely, meaning that tax havens are here to stay.

\section{DETERMINING FACTORS OF TAX HAVENS}

The choice of a tax haven may appear to be a subjective process since it must be adapted to a particular situation, and geared towards a specific economic agent. However, it is possible to make the selection procedure more efficient by following a systematic selection approach. This will require full consideration of all important fiscal and non-fiscal factors which have to be categorized according to some key factors. In this selection process study, we are considering three groups of key factor: the general factors, the particular factors and the specific factors.

1. The General Factors: these factors are related to the economic, political, fiscal and financial situations of the country. The tax haven seeker must ensure the adequacy of certain elements: 1) A minimum period of existence; 2) A minimum political consensus; 3) The geographical situation, the transport facilities and the communication facilities; 4) Political and economic stability; 5) An adequate social structure: banking, accounting, judicial, humanitarian; 6) A stable currency and a controlled exchange rate; and 7) Other general factors. The analysis of these factors will help eliminate non-compatible locations where "culture" may clash undesirably. In essence, many tax havens are located in remote regions, where access to proper infrastructure is difficult to come by. Population is also minimal in many of these territories. Moreover, the climate and socio-cultural values of the region may not be compatible with the modernized world accustomed by the westerner.

2. The Particular Factors: these factors refer to one's personal objective in searching a tax haven. Among them are: 1) Residency; 2) Capital tranfer; 3) The Trips, 4) Operations within a Tax Haven; and 5) The Utilization of Tax Treaties. These benefits vary from one country to another. So it is important to "shop" around for the nation that best meets the tax haven seeker's objective. Professional tax specialists are able to identify flaws within the treaties of such nations for the benefit of the tax haven seeker.

3. The Specific Factors: these factors are related to the nature of tax havens that varies from one country to another. Luxembourg, for example is only a tax haven because of its holding societies. Liberia forms an interesting example of a tax haven. In Liberia, formal constitution is simplified, there is no overseeing control of trade, the money is legal tender and the currency is in US dollars. Singapore, the Bahamas and Bahrain have become the most important financial centers that have facilitated the creation of non-resident banks operating on foreign ground. These specifications can help the tax haven seeker to streamline his choice of tax havens. These groups of key factors are used in the formulation of the suggested tax haven selection methodology.

Overall, the appropriateness of a country as a tax haven is difficult to determine and can be subjective since two countries may offer one or many of the same advantages available in tax havens. While all tax haven seekers are mutually motivated by the same lucrative financial incentives offered by tax shelters they are also seeking at various levels the confidentiality, the security, and the facility to escape problematic successor vices, such as an estate war or a messy divorce. Opportunities are readily available for both a person wishing to live locally or for one who desires to oversee operations from abroad. Nevertheless, before making a decision, the user of this tax system must consider whether he or she is willing and able to reside as a formal resident in the chosen haven. To be an optimum choice, a 
tax haven selection has to take into account both quantitative and qualitative factors. So far, few if any of the tax haven selection approach integrated these two factors simultaneously into their analysis. This paper attempts to integrate such factors into its tax haven selection methodology by using an analysis based on a variant of Gibson \& Brown's location model.

\section{A MULTICRITERIA TAX HAVEN SELECTION APPROACH}

The objective of this multicriteria selection is to combine all pertinent determining factors mentioned in such a way to come out with a rational measure of choice (MC) among a set of competing tax havens. The suggested approach is a variant of Gibson \& Brown's location model 1982. Similar to Gibson \& Brown's model, the proposed model integrates three categories of key factors: critical, objective, and subjective factors. For each "tax haven" i, the measure of choice (MCi) is defined by the following equation:

$$
\begin{aligned}
& M C_{i}=M C F_{i}\left[X \times M O F_{i}+(1-X) \times M S F_{i}\right] \\
& \text { Where } \\
& M C F_{i}=\text { measurement of the critical factor of tax haven } i \text { with } M C F_{i} \in[0,1] \\
& M O F_{i}=\text { measurement of the objective factor of tax haven } i \text { where } 0 \leq M O F_{i} \leq 1 \text { with } \sum M O F_{i}=1 \\
& M S F_{i}=\text { measurement of the subjective factor of tax haven } i \text { where } 0 \leq M S F_{i} \leq 1 \text { with } \sum M S F_{i}=1 \\
& X \quad=\text { objective indicator of the decision where } 0 \leq X \leq 1
\end{aligned}
$$

The $\mathrm{MOF}_{\mathrm{i}}$ measurement factor is given by:

$$
M O F_{i}=G O F_{i} \times \sum_{i} \frac{1}{G O F_{i}} \div \sum_{i}\left[G O F_{i} \times \sum_{i} \frac{1}{G O F_{i}}\right]
$$

Where

$G O F_{i}=$ the gain on the objective factor or the potential advantage derived from haven $i$.

In this expression, the sum of all $\mathrm{MOF}_{\mathrm{i}}$ equals 1. A high value of $\mathrm{MOF}_{\mathrm{i}}$ corresponds to an attractive tax haven.

The $\mathrm{MSF}_{\mathrm{i}}$ measurement factor is given by:

$$
M S F_{i}=\sum_{i}\left(W S F_{k} \times W W_{i k}\right)
$$

Where

$W S F_{k}=$ integration of the subjective factor $k$ as compared to other subjective factors

$W W_{i k}=$ integration of 'haven' $i$ as compared to all other havens relating to subjective factor $k$

The value of the critical factor (MCFi) of a tax haven $i$ is equal to 1 when this tax haven satisfies the critical criterion. Otherwise, it is null and leads to the elimination of the haven i as a potential candidate. The critical factor's main goal is to resolve the critical aspects of the choice. The non-respect of these criterion leads to rejection as a tax haven candidate. The objective factors are easily quantifiable and may eventually be expressed in monetary terms. They also allow a classification among tax haven candidates. The measurement of the objective factor (MOF) is expressed in percentage to permit a comparison between the objective and subjective factors. To maintain an invariant deviation ratio between the advantages of different tax havens, the measurement MOFi is expressed in terms of advantages related to the objective factors. The higher the value of MOFi for a tax haven, the higher its attractiveness. Finally, the third category of factors constitutes the subjective factors that are mostly qualitative and are thus difficult to quantify. The organigram of the proposed model is presented in the following diagram. 


\section{Organigram of the Selection Process for a Tax Haven}

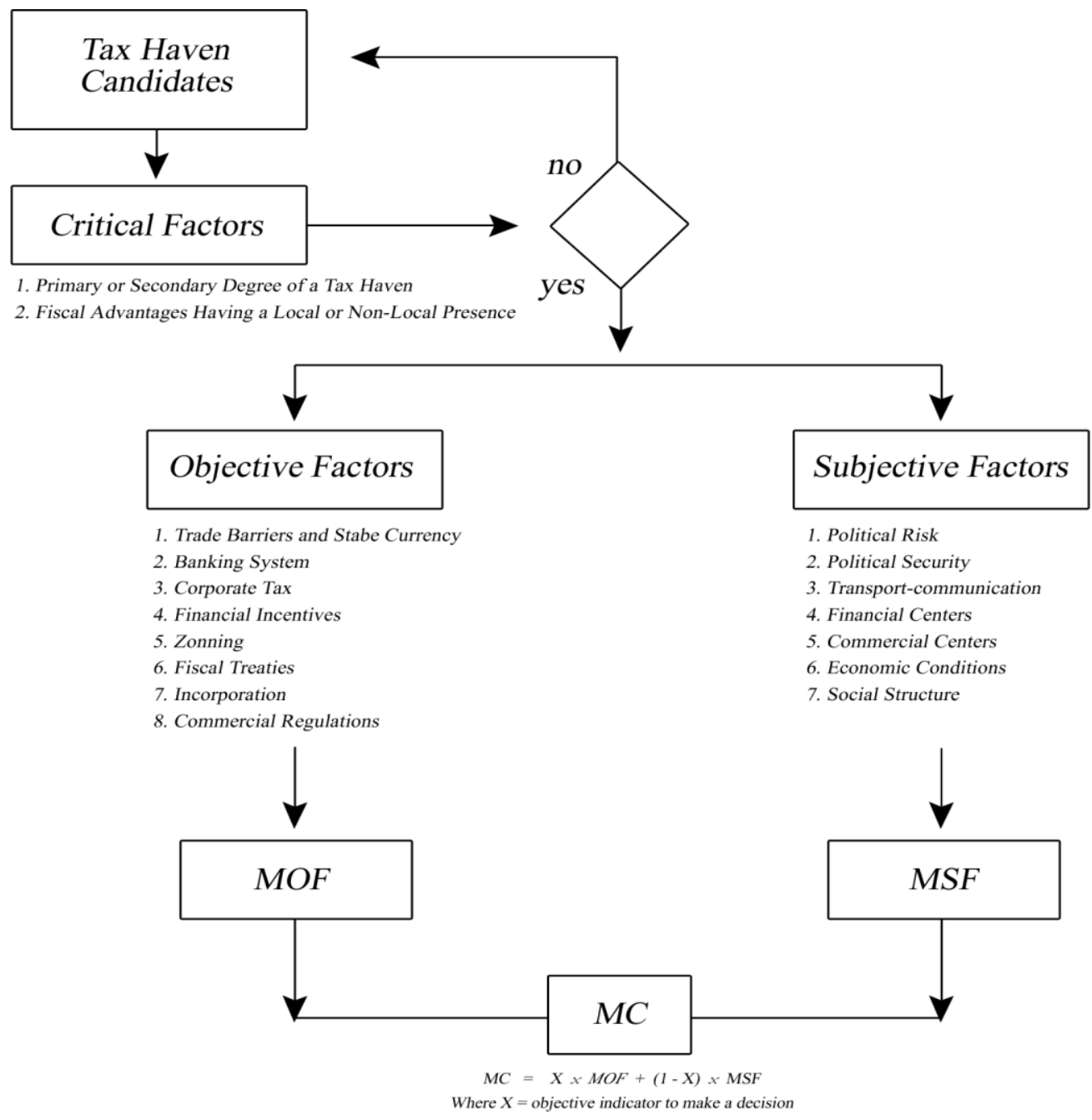

Given this approach, the values of the subjective factor (MSFi) of the tax haven i depend mainly on the relative importance of each subjective factor and the relative importance of the tax haven $i$ in conjunction with other countries for each of the subjective factors. The weighting of the subjective factors is determined with a comparison based on the theory of preference. The procedure consists of a comparison between two subjective factors in a double entry table. If the first factor is preferred to the second, a value of 1 is assigned to the first factor and the value of 0 to the second and or vice-versa. If the two factors are equally preferable, then the value of 1 is assigned to both. Finally, for comparison evaluation reasons, the values of (MSFi) are normalized. So, for a given factor, the total value for all tax havens combined equals 1.

Finally, the value of the decision indicator $\mathrm{X}$ establishes the relative importance between the objective and subjective factors for a given individual. This value can be adjusted to reflect the perception and preference of the tax haven seeker. And as the $\mathrm{X}$ value reflects the preferences of a tax haven seeker, the measure of choice (MCi) will allow him to determine the most appropriate tax haven for his overall situation. The tax haven with the highest MCi becomes his most promising choice. 
The following is an illustration of the approach. The empirical aspect of the paper deals with a set of 6 tax havens out of 40 country candidates with the following characteristics: 2 critical factors, 8 objective factors and 7 subjective factors. The tested sample comprises Luxembourg, Ireland, the Cayman Islands, Costa Rica, Malaysia and Liberia, each representing different category of tax havens. The objective set in this analysis is to alleviate the tax haven seeker's tax burden and the critical factors are the degree of primary or secondary tax attributes and the fiscal advantages for local or non-local offshore residents. The analysis of the 8 objective factors and the 7 subjective factors are shown in evaluation tables 1 and 2 respectively. The evaluations presented in tables 1 and 2 provide a synthesis of home-grown-offshore-advice based on the correlation of the determining factors of tax havens. These tables enable the determination of the relative importance attached to series of objective and subjective factors when making the optimal choice with the assumption that the set of information provided by the tax haven seeker is independent. His choice will then depend on the level of relative importance that he or she gives to the objective and subjective factors.

Table 1 presents the advantages of the objective factors quantified on a scale of 10 . Higher values are preferable to lower ones. And Table 2 presents a summary of the subjective factors, given the collected information on the sample countries.

Table 1

Evaluation of Objective Factors on a scale of 1 to 10

\begin{tabular}{|l|c|c|c|c|c|c|}
\hline & Luxembourg & Ireland & Malaysia & Liberia & $\begin{array}{c}\text { Cayman } \\
\text { Islands }\end{array}$ & $\begin{array}{c}\text { Costa } \\
\text { Rica }\end{array}$ \\
\hline Trade Barriers and Stable Currency & 6 & 9 & 5 & 9 & 8 & 10 \\
Banking System & 10 & 9 & 8 & 6 & 9 & 8 \\
Corporate Tax & 4 & 2 & 3 & 6 & 10 & 5 \\
Fiscal Incentives & 10 & 8 & 9 & 10 & 10 & 6 \\
Zonning & 5 & 10 & 10 & 8 & 0 & 0 \\
Fiscal Treaties & 9 & 9 & 9 & 6 & 10 & 0 \\
Incorporation Abilities & 7 & 7 & 2 & 9 & 8 & 10 \\
Commercial Regulations others & 5 & 5 & 5 & 9 & 5 & 8 \\
advantages & & & & & & \\
Total & 56 & 59 & 51 & 63 & 60 & 47 \\
\hline
\end{tabular}

Table 2

Evaluation of subjective factors by attribute, based on their qualitative value between countries

\begin{tabular}{|l|c|c|c|c|c|c|}
\hline & Luxembourg & Ireland & Malaysia & Liberia & $\begin{array}{c}\text { Cayman } \\
\text { Islands }\end{array}$ & $\begin{array}{c}\text { Costa } \\
\text { Rica }\end{array}$ \\
\hline Political Risk & $\mathrm{E}$ & $\mathrm{E}$ & $\mathrm{Vg}$ & $\mathrm{P}$ & $\mathrm{Vg}$ & $\mathrm{Vg}$ \\
Security & $\mathrm{E}$ & $\mathrm{Vg}$ & $\mathrm{Vg}$ & $\mathrm{A}$ & $\mathrm{E}$ & $\mathrm{G}$ \\
Transport - Communication & $\mathrm{E}$ & $\mathrm{E}$ & $\mathrm{E}$ & $\mathrm{Vg}$ & $\mathrm{E}$ & $\mathrm{E}$ \\
Financial Centers & $\mathrm{E}$ & $\mathrm{E}$ & $\mathrm{E}$ & $\mathrm{G}$ & $\mathrm{G}$ & $\mathrm{Vg}$ \\
Commercial Centers & $\mathrm{E}$ & $\mathrm{E}$ & $\mathrm{E}$ & $\mathrm{G}$ & $\mathrm{G}$ & $\mathrm{Vg}$ \\
Economic Conditions & $\mathrm{E}$ & $\mathrm{G}$ & $\mathrm{Vg}$ & $\mathrm{G}$ & $\mathrm{E}$ & $\mathrm{A}$ \\
Social Structure & $\mathrm{E}$ & $\mathrm{Vg}$ & $\mathrm{Vg}$ & $\mathrm{G}$ & $\mathrm{A}$ & $\mathrm{Vg}$ \\
\hline
\end{tabular}

E : Excellent; Vg : Very Good; G : Good; A : Average; P : Poor

Table 3 and Table 4 present the comparative values of subjective factors derived from preference theory by calculating the WSF values and the total weight value ww. The number 1 at the intersection of the line and of the column indicates that the criteria in the line dominate the ones in columns. In our case, the results indicate that the political risk is the dominant factor in comparison to the other factors. 
Table 3

Integration of Subjective Factors WSF $_{\text {I }}$

\begin{tabular}{|l|cccccccccc|}
\hline & & $\mathbf{1}$ & $\mathbf{2}$ & $\mathbf{3}$ & $\mathbf{4}$ & $\mathbf{5}$ & $\mathbf{6}$ & $\mathbf{7}$ & $\begin{array}{c}\text { Total count } \\
\text { Preferences }\end{array}$ & Weight \\
\hline Political Risk & $\mathbf{1}$ & $\mathrm{X}$ & 1 & 1 & 1 & 1 & 1 & 1 & 6 & 0.2400 \\
Security & $\mathbf{2}$ & 0 & $\mathrm{X}$ & 1 & 1 & 1 & 1 & 1 & 5 & 0.2000 \\
Transport-communication & $\mathbf{3}$ & 0 & 1 & $\mathrm{X}$ & 1 & 1 & 1 & 1 & 4 & 0.1600 \\
Financial Centers & $\mathbf{4}$ & 0 & 0 & 0 & $\mathrm{X}$ & 1 & 1 & 1 & 3 & 0.1200 \\
Commercial Centers & $\mathbf{5}$ & 0 & 0 & 0 & 1 & $\mathrm{X}$ & 1 & 1 & 3 & 0.1200 \\
Economic Conditions & $\mathbf{6}$ & 0 & 0 & 0 & 1 & 1 & $\mathrm{X}$ & 1 & 3 & 0.1200 \\
Social Structure & $\mathbf{7}$ & 0 & 0 & 0 & 0 & 0 & 1 & $\mathrm{X}$ & 1 & 0.0400 \\
\hline Total & & & & & & & & & $\mathbf{2 5}$ & $\mathbf{1 . 0 0 0 0}$ \\
\hline
\end{tabular}

Table 4 gives the weight of the tax havens according to each subjective factor. For example, the value of 0.2631 in the table indicates that the political risk of Luxemburg represents a value of $26.31 \%$ as compared to the political risks exhibited in other countries. The higher the number, the better it is, which translates to an advantageous political situation for this particular country.

Table 4

Integration of Havens as Compared to Other Subjective Factors

\begin{tabular}{|c|c|c|c|c|c|c|}
\hline $\begin{array}{ll}\text { Subjective } & \text { Haven } \\
\text { Factors } & \end{array}$ & Luxembourg & Ireland & Malaysia & Liberia & $\begin{array}{l}\text { Cayman } \\
\text { Islands }\end{array}$ & $\begin{array}{c}\text { Costa } \\
\text { Rica }\end{array}$ \\
\hline $\begin{array}{l}\text { Political Risk } \\
\end{array}$ & .2631 & .2631 & .1579 & .0000 & .1579 & .1579 \\
\hline Security & .2941 & .1765 & .1765 & .0000 & .2941 & .0588 \\
\hline Transport-Communication & .2000 & .2000 & .2000 & .0000 & .2000 & .2000 \\
\hline Financial Centers & .2631 & .2631 & .2631 & .0526 & .0526 & .1052 \\
\hline Commercial Centers & .2631 & .2631 & .2631 & .0526 & .0526 & .1052 \\
\hline Economic Conditions & .2941 & .1765 & .1765 & .0000 & .2941 & .0588 \\
\hline Social Structure & .2000 & .2000 & .2000 & .0000 & .2000 & .2000 \\
\hline
\end{tabular}

The estimated values of the different objective measured factors (MOF), subjectives (MSF) and the measurement of choice (MC) are shown in table 5. For example, the column containing the values of MOF in table 5 gives an evaluation of the objective factors. Based on this evaluation, a tax haven selection approach that relies uniquely on the objective factors will classify Liberia as the most desirable tax haven mainly because of its low tax rate for holding corporations, followed by Cayman Islands. Costa Rica would be the least desirable tax haven according to the objective factors.

Table 5

Measurement of Choice $\mathrm{MC}_{\mathrm{i}}(\mathrm{X}=.80)$

\begin{tabular}{|l|c|c|c|c|}
\hline \multicolumn{1}{|c|}{ Haven } & MFC $_{\mathbf{i}}$ & MOF $_{\mathbf{i}}$ & MSF $_{\mathbf{i}}$ & MC $_{\mathbf{I}}$ \\
\hline Luxembourg & 1 & .1667 & .2604 & .1854 \\
Ireland & 1 & .1756 & .2228 & .1850 \\
Malaysia & 1 & .1518 & .1975 & .1610 \\
Liberia & 1 & .1875 & .0127 & .1525 \\
Cayman Islands & 1 & .1786 & .1846 & .1798 \\
Costa Rica & 1 & .1398 & .1220 & .1363 \\
\hline
\end{tabular}


Knowing the actual instability situation in Liberia, very few will be willing to choose Liberia. However, once the subjective factors are integrated into the model with an objective indicator of eighty percent $(\mathrm{X}=.80)$, Luxembourg is ranked first as the most desirable tax haven with a value of MC equals 0.2604 . And Liberia, which was rank first with $X=100 \%$ is now classified as the least desirable tax haven. This result shows how sensitive the analysis could be. Just by weighting $20 \%$ of the subjective factors into the MC has shifted Liberia's ranking around, from being the most desirable to the least desirable. This indicates the importance of subjective factors in this analysis. Evidently, a ranking derived from subjective factors only; $(\mathrm{X}=0)$ will favour Luxemburg compared to other countries. A detail sensitivity analysis for the MC is presented in Table 6.

Table 6

Sensitivity Analysis

\begin{tabular}{|l|c|c|c|c|c|c|c|}
\hline \multicolumn{1}{|c|}{ Tax Haven } & $\mathbf{0}$ &. $\mathbf{2}$ & $\mathbf{. 4}$ & $\mathbf{. 5}$ & $\mathbf{. 6}$ & $\mathbf{. 8}$ & $\mathbf{1}$ \\
\hline Luxembourg & .2604 & .2416 & .2229 & .2135 & .2042 & .1854 & .1667 \\
Ireland & .2228 & .2134 & .2039 & .1992 & .1945 & .1850 & .1756 \\
Malaysia & .1975 & .1883 & .1732 & .1746 & .1701 & .1610 & .1518 \\
Liberia & .0127 & .0477 & .0826 & .1001 & .1176 & .1525 & .1875 \\
Cayman Islands & .1846 & .1834 & .1822 & .1816 & .1810 & .1798 & .1786 \\
Costa Rica & .1220 & .1256 & .1292 & .1310 & .1326 & .1363 & .1398 \\
\hline
\end{tabular}

According to this study, it is obvious that the tax haven seeker has much to gain by establishing himself in Luxembourg, as opposed to other countries studied. A sensitivity analysis based on different values of the objective value of decision $X$, where the result appears in table 6, clearly shows that for all values of $X$ where $X$ is inferior or equal to $80 \%$, Luxembourg is preferred compared to all other countries among the group and this confirms that Luxembourg is relatively stable. It is only with a value of $X=90 \%$ that Luxembourg is comes after Liberia and the Cayman Islands in terms of tax haven attractiveness.

The major advantage of this analytical tool is in its capacity to integrate both quantitative and qualitative factors into a model and to derive a decision index to help solve selection problems with subjective and objective attributes. The usage of such an analytical model based on multi-criteria is more and more common in situations where the decision requires more than an objective function and where the quantification is difficult to assess. Among other portfolio evaluation studies, the proposed methodology can also be used in constructing hedge fund portfolios, as it will allow consideration all pertinent factors in the selection process.

\section{CONCLUSION}

The main objective of this paper is to demystify tax havens and to develop an analytical process to assist an individual in his search for the most appropriate tax haven for his needs. The amount of effort deployed by anti-tax haven agencies and by international services to obstruct the development of tax havens is a measure of their importance around the world and at the same time, increases their popularity. Those who are ignoring the potential use of tax havens in their planning are depriving themselves of potential gains from a well-designed plan. Many legal ways exist to protect an investor's wealth from governmental authorities in order to reduce one's tax burden. Knowing such methods is a key to proper managerial finance both at a corporate and an individual level. This way of thinking is in line with the concept that it is up to individuals to make the necessary arrangements, within the existing legislation, to reduce their tax burden. Up to now, few proven processes exist to help individuals seeking a tax haven. Using a variant of a multicriteriat analysis based on Gibson \& Brown, this paper presents a rationalized process to integrate both objective and subjective tax haven factors into a decision index to assist individuals in choosing the most appropriate tax haven according to their personal preferences. The paper also shows that the subjective factors are equally important in the tax haven assessment. This leads to conclude that any choice of a tax haven solely based on quantitative factors like tax rates will fail to lead to one's most preferable choice. Qualitative factors such as political stability, adequate technological resources and cultural-social structures are equally important when making 
a selection decision. While our multicriteriat model is very appealing, the usefulness of its result will mainly depend on the correctness and the completeness of the information entered into the model, which requires a serious work of quantification of all factors for all countries at any given moment. Unfortunately, such information is accessible to only a handful of tax specialist professionals, and is seldom readily available to the general public.

\section{REFERENCES}

1. Beauchamp, André. "Guide mondial des paradis fiscaux ”. Éditions Grasse et Fasquelle, 1992.

2. Brittain-Catlin, William "Offshore: Tax Havens, Secrecy, Financial Manipulation and the Offshore Economy” Multinational Monito, Washington: Jul/Aug 2005. Vol. 26, Iss. 7/8; pg. 47, 5 pgs

3. Brown, P.A. and D.F. Gibson, "A quantified Model for Site Selection : Application to a Multiplant Location Problem", AIIE Transactions, March 1982

4. Dauphin, Claude. 'Le Guide Vraiment Pratique des Paradis Fiscaux’ Editions First-Pratique 1998

5. Diamond W and Dorothy Diamond. "Tax Heavens of the World". Éditions Matthew Bender, 1982

6. Doggart, Caroline. "Tax Havens and their uses" (originally published 1990)". Economist Intelligence, Unit, ISBN 0862181631.

7. Friedman Milton and Rose friedman: Free to Choose: A Personal Statement. Editions: Books: Milton Friedman January 1980

8. Rawlings, Gregory, "Taxes and Transnational Treaties: Responsive Regulation and the Reassertion of Offshore Sovereignty". Law \& Policy. Oxford: Jan 2007. Vol. 29, Iss. 1; pg. 51

9. Tax Justice Network: http://www.economist.com/surveys/displaystory.cfm?story_id=8695139

1. "NO TAX HAVENS"

These are countries with no personal or corporate income, capital gains, or wealth taxes. These places are ideal for incorporating a business or for forming a trust. In return for the surplus of liquid funds, the governments of these countries impose small fees on documents of incorporation, a charge on the value of corporate shares and annual registration fees. Such societies are easy to create and are popular for trust creation. ${ }^{8}$

2. "NO TAX ON FOREIGN INCOME" HAVENS

Countries in this category do not impose taxes on income earned abroad. In addition, the laws in these nations usually exempt income derived from the export of local manufactured goods, since these countries wish to encourage domestic industrial expansion and local jobs. ${ }^{8}$ The "no-tax-on-foreign-income-havens" are broken down into two main groups. There are those; 1) that allow a corporation to do business both internally and externally, taxing only the income coming from internal domestic sources; and, 2) those requiring a company to choose at the time of incorporation whether it will do business locally, with consequent tax liabilities, or will do only foreign business locally, with the consequent tax liabilities, or will do only foreign business, and thus be exempt from taxation. ${ }^{8}$ Primary examples in these two categories are the Republic of Panama, the British colony of Gibraltar and the United Kingdom-associated islands of Jersey, Guernsey, and the Isle of Man. ${ }^{8}$ These are countries where tax is imposed on revenue that has been earned within the host country. A society created in these countries can generate monies without being obliged to pay tax on the earnings, providing they are not incoming from the source country.

3. "LOW TAX" HAVENS

Countries in this status impose some taxes on all corporate income, wherever earned worldwide. However, most have international double-taxation agreements with high-tax countries, that may reduce with withholding tax imposed on income earned in the high-tax countries by the local corporations. Cyprus is a primary example. Barbados is another low-tax country (with a $2.5 \%$ tax on corporate income) that is popular with western business people. ${ }^{8}$

4. "SPECIAL" TAX HAVENS

These countries impose all of the usual taxes with the exception that they allow valuable tax concessions and flexibility, writeoffs or "holidays" to special types of companies that would benefit the economy. The Netherlands and Ireland are particularly good examples of nations, which offer major tax concessions to selected foreign businesses. ${ }^{8}$

5. Other countries offer miscellaneous advantages that go according to personal preference. 


\section{NOTES}

